\title{
Factors Affecting the Implementation of Smart Education in Indonesia: A Systematic Review
}

\author{
Turuy $\mathrm{Seh}^{*}$ Arief Asaf, and Latif Lita Asyarif \\ Smart City Islands Research Group Laboratory of Faculty of Engineering, Universitas Khairun, 97719, Ternate, Indonesia
}

\begin{abstract}
The educational progress of an area is determined by the way the government manages its education system. Smart education is a learning concept that utilizes 21 st-century skills by following the latest technological innovations. Not all regions are able and ready to implement the concept. This study utilizes the Systematic Review method to identify what factors need to be considered in implementing smart education based on previous studies. The research resulted in five main interrelated aspects of all the factors found in previous studies, namely technological aspects, data aspects, H.R. aspects, organizational aspects, and cost aspects. By paying attention to all the factors from these five aspects, it will increase the level of success of the government in implementing smart education.
\end{abstract}

Keywords: Smart Education, Systematic Review, Factors Affecting

\section{Introduction}

Based on CEOWorld Magazine conducted research related to education in 2020 , one of the results showed the ranking of the education system in Indonesia was at 70 th out of a total of 93 countries studied [1]. The assessment was carried out from January to April 2020, when the world was at the beginning of the Covid-19 pandemic, by prioritizing aspects of quality and opportunity. The quality aspect is focused on the public education system, while the opportunity is focused on the school graduation rate [1]. The education system that has changed in a short time from face-to-face to online Learning has not been well anticipated by the government in Indonesia [2]. For example, teachers find it difficult to adapt the K-13 curriculum to the online learning system, teachers and students lack knowledge of distance learning technology, additional internet quota fees, and the additional work of parents in assisting children in Learning [3][4]. From Indonesia 2019 education statistics, the school graduation rate is also still lacking. For example, at the high school level which has been required by the government, the graduation rate has only reached $62.2 \%$ [5].

Gradually, several cities/districts in Indonesia have carried out digital transformation by implementing the smart city concept. According to Law Number 24 of 2014 concerning regional government, one of the six basic services prioritized in the smart city concept is education services, which can be implemented through the smart education concept [6][7]. The need for digital transformation to improve the quality of the education system, which will continue into the new normal era, must be seriously considered by the government. The transformation carried out in the smart education concept does not only change the curriculum and learning methods offline to online, so the government must know what factors affect the implementation process so that all parties involved are institutions more prepared, but the transformation also runs smoothly, and the risk of failure can be avoided [8][9].

The purpose of this study is to make a summary of what factors need to be considered by local governments in implementing the smart education concept based on previous studies using the Systematic Review (S.R.) methodology. It is hoped that this research will become one of the references for the government in starting the development of the smart education concept in their area.

\section{Theoretical Basis}

\subsection{Systematic Review (S.R.)}

The Smart City (smart city) is a city concept where the community is able to utilize technological resources efficiently and intensively to increase economic growth and comfort of life [10][9] [11]. One of the services that must be developed in implementing the smart city concept is education services (smart education).Smart education itself is a learning concept that utilizes 21 st-

\footnotetext{
* Corresponding author: seh.turuy26@gmail.com
} 
century skills, which is student-centred with the support of advanced and integrated I.T. infrastructure so that the learning process is more interactive, innovative, and comprehensive [9][8][12]. The novelty of technology used in the process and manufacture of learning products on the concept of smart education must be able to provide opportunities and access to proper education for all elements of society [8].

Some of the technologies used to support the application of the smart education concept based on the analysis of [13] are as follows.

1. Social Media, i.e. facebook, LinkedIn, Instagram, Wikipedia.

2. Collaborative Learning, several students work together to achieve something, solve a problem, or complete a project.

3. Mobile Learning, learning through smartphone media with the help of an internet connection.

4. Edutainment/Gamification, designed to entertain as well as educate. For example, a game that requires students/players to answer science questions.

5. Digital Pedagogy, the use of digital technology in the teaching and learning process by digitizing the subject matter.

6. Massive Open Online Course (MOOC), an online course that can be accessed by anyone.

7. Blended Learning, mixed Learning that involves online systems and face-to-face meetings.

8. Flipped Classroom, students get learning materials before class online and they take advantage of class time in a discussion.

9. Open Educational Resources (O.E.R.s), educational materials that are in the public domain or introduced under an open license. It can be a textbook containing a syllabus, assignment notes, projects, animations, and more.

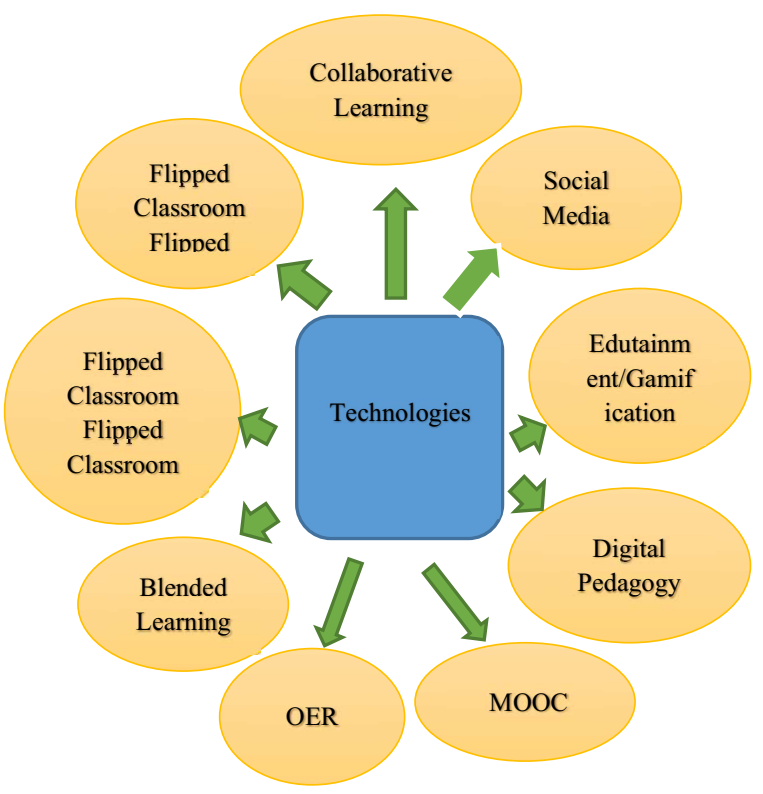

Fig. 1. Technology that supports the implementation of Smart Learning [13].

\subsection{Smart Education}

S.R. approach is one of the methods used by researchers to refer to available research or research methodologies that are relevant to the topic area and research questions so that interpretation and evaluation can be carried out [14][15]. Research with the S.R. method aims to provide a more precise evaluation using a reliable, rigorous, and auditable methodology that is usually required in a study [14][15].

In the implementation of the S.L.R., there are three stages, namely: the first stage is an introduction, which includes the scope of determining research questions. The second stage is the process of determining search sources and selecting keywords. And the last stage is to determine the inclusion and exclusion criteria used to classify the type of research, then extract data from the selected research for further exploration [16].

\section{Methodology}

In presenting a literature review to identify factors that can influence the implementation of smart education, we will use the S.R. methodology based on research [17].

1. SLR Protocol, Mendefinisikan pertanyaan penelitian, sumber pencarian, kondisi pencarian, strategi pencarian, kriteria khusus, maupun kriteria yang dihindari.

2. Search for Literature, melakukan pencarian literatur pada sumber yang telah ditentukan.

3. Select Literature, Menyeleksi hasil pencarian literatur yang terkait dengan kata kunci pertanyaan penelitian.

4. Summarize Evidence, Menyimpulkan isi dari semua literatur yang telah dipilih.

5. Disseminate Result, menuliskan hasil penelitian ke dalam sebuah laporan karya tulis.

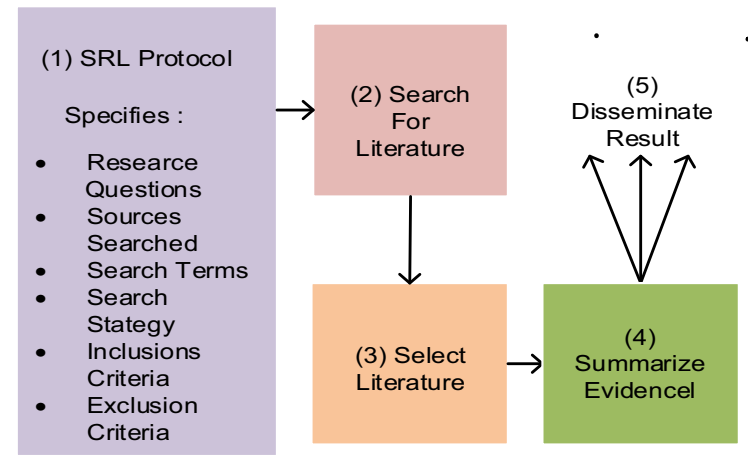

Fig. 2. Illustration of the S.R. process in the IS/IT domain [17].

\subsection{S.R. Protocol}

Based on the process in Figure 2, the research S.R. protocol can be defined as follows: 
Table 1. Protokol SR.

\begin{tabular}{|c|l|}
\hline S.R Protocol & \multicolumn{1}{|c|}{ Description } \\
\hline Research Question & $\begin{array}{l}\text { What factors do local governments } \\
\text { consider in implementing Smart } \\
\text { Education }\end{array}$ \\
\hline - $\begin{array}{l}\text { ACM Digital Library } \\
\text { (http://portal.acm.org) }\end{array}$ \\
- IEEEXplore \\
(http://ieeexplore.ieee.org) \\
MECS Press (http://www.mecs- \\
press.org/) \\
Seurce & $\begin{array}{l}\text { Science Direct } \\
\text { (http://www.sciencedirect.com) }\end{array}$ \\
\hline $\begin{array}{l}\text { SpringerLink } \\
\text { (http://ink.springer.com) }\end{array}$ \\
\hline ("Smart Education" OR "Smart \\
Learning")
\end{tabular}

\subsection{Implementation}

Search results from all sources by entering the appropriate keywords found 553 scientific papers. The paper was published between 2016 and 2020 and is related to Smart Education or Smart Learning. Table 2 shows the selection of data from each search source.

Table 2. Selection of data from each search source

\begin{tabular}{|c|c|c|c|}
\hline Source & $\begin{array}{c}\text { Paper } \\
\text { Found }\end{array}$ & $\begin{array}{c}\text { Candidate } \\
\text { papers }\end{array}$ & $\begin{array}{c}\text { Selected } \\
\text { Paper }\end{array}$ \\
\hline IEEExplore & 198 & 40 & 6 \\
\hline ACM & 59 & 15 & 4 \\
\hline SpringerLink & 14 & 12 & 6 \\
\hline MECS & 14 & 6 & 3 \\
\hline ScienceDirect & 74 & 9 & 1 \\
\hline Total & $\mathbf{3 5 9}$ & $\mathbf{8 2}$ & $\mathbf{2 0}$ \\
\hline
\end{tabular}

Of the 461 papers found, 20 selected papers were found. An illustration of the selection process is shown in Figure 3.

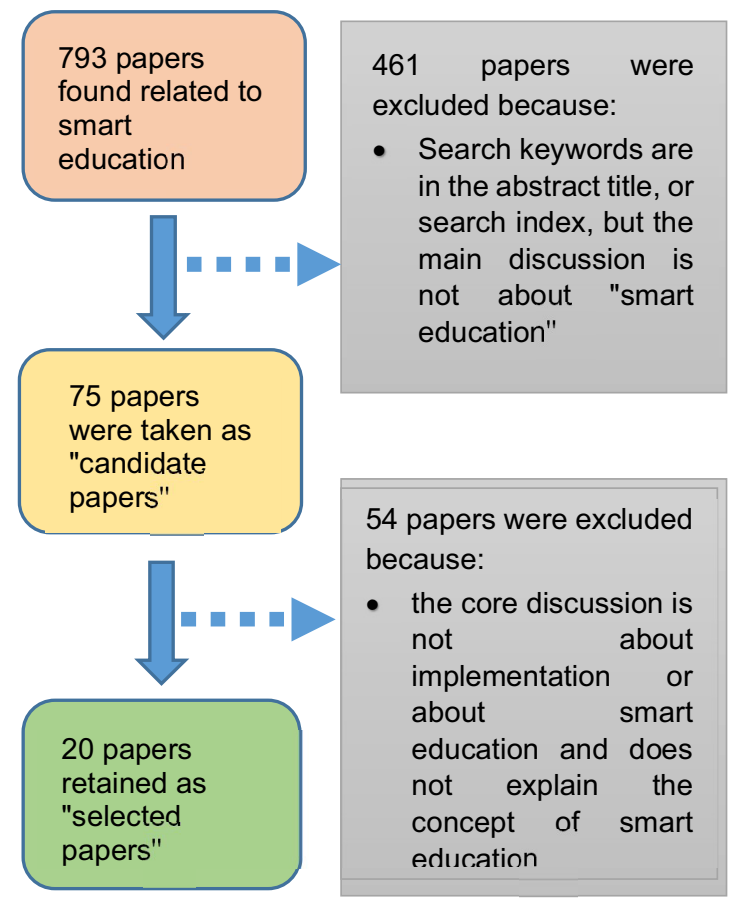

Fig. 3. Results of the process of searching for library sources

\section{Results And Discussion}

\subsection{Literature Distribution}

The literature search results published in the last five years, namely between 2016 and 2020, have produced 20 papers for further research. Figure 4 shows the distribution of the number of papers per year, which increases in 2019 but decreases again in 2020. The distribution of types of papers is shown in Figure 5, which shows there are nine journal type papers and 12 papers from conference results.

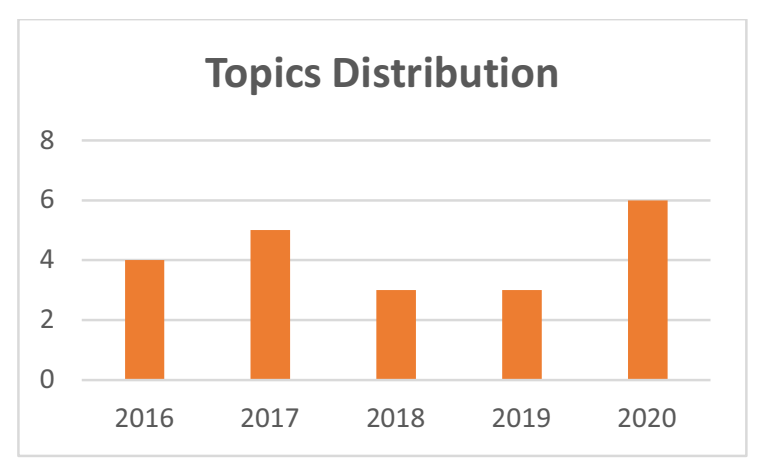

Fig. 4. Distribution of papers every year 


\subsection{Paper Selection}

Based on SLR protocol, the purpose of this study is to find out what factors can affect the process of implementing smart education. Table 3 contains a list of selected references related to the implementation of smart education.

Table 3. Literature source.

\begin{tabular}{|c|c|c|c|c|}
\hline $\begin{array}{l}\text { S.I. } \\
\text { D. }\end{array}$ & Title & Source & Year & Type \\
\hline S1 & $\begin{array}{l}\text { Towards a Smart } \\
\text { Learning [18] }\end{array}$ & $\mathrm{ACM}$ & 2016 & $\begin{array}{l}\text { Confere } \\
\text { nce }\end{array}$ \\
\hline $\mathrm{S} 2$ & $\begin{array}{l}\text { Measuring Smart } \\
\text { Education [19] }\end{array}$ & $\mathrm{ACM}$ & 2018 & $\begin{array}{l}\text { Confere } \\
\text { nce }\end{array}$ \\
\hline S3 & $\begin{array}{l}\text { How Smart } \\
\text { Are[20] }\end{array}$ & $\mathrm{ACM}$ & 2019 & Journal \\
\hline S4 & $\begin{array}{l}\text { Smart School } \\
\text { Guidance[21] }\end{array}$ & $\mathrm{ACM}$ & 2019 & $\begin{array}{l}\text { Confere } \\
\text { nce }\end{array}$ \\
\hline S5 & The future of [22] & $\mathrm{ACM}$ & 2020 & $\begin{array}{l}\text { Confere } \\
\text { nce }\end{array}$ \\
\hline S6 & $\begin{array}{l}\text { ICT and internet } \\
{[23]}\end{array}$ & $\begin{array}{l}\text { IEEEXplo } \\
\text { re }\end{array}$ & 2016 & $\begin{array}{l}\text { Confere } \\
\text { nce }\end{array}$ \\
\hline S7 & $\begin{array}{l}\text { Smart learning } \\
{[24]}\end{array}$ & $\begin{array}{l}\text { IEEEXplo } \\
\text { re }\end{array}$ & 2016 & $\begin{array}{l}\text { Confere } \\
\text { nce }\end{array}$ \\
\hline S8 & $\begin{array}{l}\text { Edukas } \\
\text { environment [10] }\end{array}$ & $\begin{array}{l}\text { IEEEXplo } \\
\text { re }\end{array}$ & 2017 & $\begin{array}{l}\text { Confere } \\
\text { nce }\end{array}$ \\
\hline S9 & $\begin{array}{l}\text { Smart education in } \\
\text { Yunnan, China } \\
{[25]}\end{array}$ & $\begin{array}{l}\text { IEEEXplo } \\
\text { re }\end{array}$ & 2017 & $\begin{array}{l}\text { Confere } \\
\text { nce }\end{array}$ \\
\hline $\mathrm{S} 10$ & $\begin{array}{l}\text { The Knowledge } \\
{[26]}\end{array}$ & $\begin{array}{l}\text { IEEEXplo } \\
\text { re }\end{array}$ & 2018 & $\begin{array}{l}\text { Confere } \\
\text { nce }\end{array}$ \\
\hline S11 & $\begin{array}{l}\text { Factors } \\
\text { considered }[16]\end{array}$ & $\begin{array}{l}\text { IEEEXplo } \\
\text { re }\end{array}$ & 2019 & $\begin{array}{l}\text { Confere } \\
\text { nce }\end{array}$ \\
\hline $\mathrm{S} 12$ & Review on [27] & $\begin{array}{l}\text { IEEEXplo } \\
\text { re }\end{array}$ & 2019 & $\begin{array}{l}\text { Confere } \\
\text { nce }\end{array}$ \\
\hline S13 & $\begin{array}{l}\text { Smart } \\
\text { Classroom[28] }\end{array}$ & $\begin{array}{l}\text { IEEEXplo } \\
\text { re }\end{array}$ & 2019 & $\begin{array}{l}\text { Confere } \\
\text { nce }\end{array}$ \\
\hline S14 & Analyses of [29] & MECS & 2018 & Jounal \\
\hline S15 & $\begin{array}{l}\text { Rural } \\
\text { Empowerment } \\
\text { [30] }\end{array}$ & MECS & 2020 & Journal \\
\hline S16 & Five trends of[31] & $\begin{array}{l}\text { Science } \\
\text { Direct }\end{array}$ & 2020 & Journal \\
\hline S17 & $\begin{array}{l}\text { A research } \\
\text { framework of } \\
\text { smart [12] }\end{array}$ & $\begin{array}{l}\text { SpringerL } \\
\text { ink }\end{array}$ & 2016 & Journal \\
\hline S18 & $\begin{array}{l}\text { Citizen } \\
\text { experiences [32] }\end{array}$ & $\begin{array}{l}\text { SpringerL } \\
\text { ink }\end{array}$ & 2017 & Journal \\
\hline S19 & $\begin{array}{l}\text { Smart learning } \\
\text { [33] }\end{array}$ & $\begin{array}{l}\text { SpringerL } \\
\text { ink }\end{array}$ & 2017 & Journal \\
\hline S20 & Smart learning[34] & $\begin{array}{l}\text { SpringerL } \\
\text { ink }\end{array}$ & 2018 & Journal \\
\hline $\mathrm{S} 21$ & $\begin{array}{l}\text { Smart educational } \\
\text { tools and learning } \\
{[35]}\end{array}$ & $\begin{array}{l}\text { Springer } \\
\text { Link }\end{array}$ & 2020 & Journal \\
\hline
\end{tabular}

\subsection{Factor Mapping}

Based on the literature that has been collected, then mapping is carried out on each literature related to what factors need to be considered in implementing the smart education concept. The results of the process with the S.R. method contained many factors, the researchers took the factors discussed by more than one reference. Mapping produces 17 factors as shown in table 4 .

Table 4. Literature Mapping Influential factors and reference sources.

\begin{tabular}{|c|c|c|}
\hline FID & Factor & Reference source \\
\hline F1 & $\begin{array}{l}\text { Internet } \\
\text { Network }\end{array}$ & $\begin{array}{l}\text { S1, S2, S3, S4, S5, S6, S7, S8, } \\
\text { S9, S10, S11, S12, S13, S14, } \\
\text { S15, S16, S17, S18, S19, S20, } \\
\text { S21 }\end{array}$ \\
\hline $\mathrm{F} 2$ & $\begin{array}{l}\text { Date } \\
\text { Server/Cloud } \\
\text { Computing }\end{array}$ & $\begin{array}{l}\text { S1, S2, S4, S5, S6, S7, S8, S9, } \\
\text { S12, S15, S17, S19, S20, S21 }\end{array}$ \\
\hline F3 & $\begin{array}{l}\text { Communication } \\
\text { device }\end{array}$ & $\begin{array}{l}\text { S1, S2, S3, S4, S5, S6, S7, S9, } \\
\text { S11, S12, S13, S16, S17, S18, } \\
\text { S19, S20, S21 }\end{array}$ \\
\hline F4 & $\begin{array}{l}\text { Physical } \\
\text { classroom }\end{array}$ & $\begin{array}{l}\text { S3, S4, S7, S8, S9, S10, S11, } \\
\text { S12, S13, S14, S15, S16, S17, } \\
\text { S18, S19, S20, S21 }\end{array}$ \\
\hline F5 & $\begin{array}{l}\text { Virtual Class } \\
\text { (e-Learning) }\end{array}$ & $\begin{array}{l}\text { S2, S4, S5, S6, S7, S8, S9, S10, } \\
\text { S11, S12, S16, S17, S18, S19, } \\
\text { S20, S21 }\end{array}$ \\
\hline F6 & $\begin{array}{l}\text { Trend } \\
\text { Technology/ } \\
\text { Application }\end{array}$ & $\begin{array}{l}\text { S1, S2, S3, S4, S5, S6, S7, S8, } \\
\text { S9, S10, S11, S12, S13, S14, } \\
\text { S15, S16, S17, S18, S19, S20, } \\
\text { S21 }\end{array}$ \\
\hline F7 & $\begin{array}{l}\text { Monitoring } \\
\text { system } \\
\text { (monitoring) }\end{array}$ & S5, S6, S7, S8, S13, S17, S21 \\
\hline F8 & $\begin{array}{l}\text { Data security } \\
\text { and User } \\
\text { privacy }\end{array}$ & $\begin{array}{l}\text { S1, S2, S3, S5, S7, S8, S12, S15, } \\
\text { S16, S18, S21 }\end{array}$ \\
\hline F9 & $\begin{array}{l}\text { Data and } \\
\text { application } \\
\text { integration }\end{array}$ & $\begin{array}{l}\text { S1, S2, S4, S5, S7, S8, S9, S10, } \\
\text { S11, S12, S13, S14, S15, S16, } \\
\text { S17, S20, S21 }\end{array}$ \\
\hline F10 & $\begin{array}{l}\text { Source or } \\
\text { material } \\
\text { learning }\end{array}$ & $\begin{array}{l}\text { S3, S5, S6, S7, S8, S9, S10, S11, } \\
\text { S12, S13, S14, S15, S16, S17, } \\
\text { S18, S19, S20, S21 }\end{array}$ \\
\hline F11 & $\begin{array}{l}\text { Lecturer } \\
\text { (Teachers, } \\
\text { Instructor) }\end{array}$ & $\begin{array}{l}\text { S1, S2, S3, S4, S5, S6, S7, S8, } \\
\text { S9, S10, S11, S12, S13, S14, } \\
\text { S15, S16, S17, S18, S19, S20, } \\
\text { S21 }\end{array}$ \\
\hline F12 & Student & $\begin{array}{l}\text { S1, S2, S3, S4, S5, S6, S7, S8, } \\
\text { S9, S10, S11, S12, S13, S14, } \\
\text { S15, S16, S17, S18, S19, S20, } \\
\text { S21 }\end{array}$ \\
\hline F13 & $\begin{array}{l}\text { Application } \\
\text { manager } \\
\text { (admin, } \\
\text { operator) } \\
\end{array}$ & $\mathrm{S} 1, \mathrm{~S} 9, \mathrm{~S} 15, \mathrm{~S} 17, \mathrm{~S} 21$ \\
\hline F14 & $\begin{array}{l}\text { Model/framewo } \\
\text { rk smart } \\
\text { education }\end{array}$ & $\begin{array}{l}\text { S1, S3, S5, S6, S7, S8, S9, S10, } \\
\text { S12, S13, S15, S16, S17, S18, } \\
\text { S19, S20, S21 }\end{array}$ \\
\hline F15 & $\begin{array}{l}\text { Rules and } \\
\text { policies }\end{array}$ & S1, S8, S9, S15, S16, S21 \\
\hline F16 & $\begin{array}{l}\text { Syllabus and } \\
\text { learning models }\end{array}$ & $\begin{array}{l}\text { S3, S8, S9, S10, S11, S12, S14, } \\
\text { S15, S16, S17, S18, S19, S20, } \\
\text { S21 }\end{array}$ \\
\hline F17 & Financing & $\mathrm{S} 5, \mathrm{~S} 7, \mathrm{~S} 15, \mathrm{~S} 16, \mathrm{~S} 21$ \\
\hline
\end{tabular}

The factors found can be categorized into 5 main aspects or factors, namely aspects of technology, data, human resources (H.R.), organization, and financing. Figure 6 
shows the aspects that affect the implementation of smart education

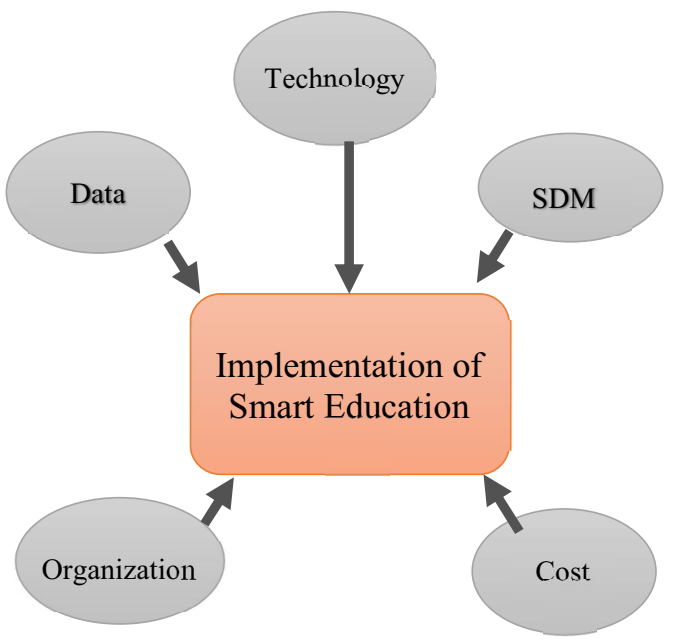

Fig. 6. Aspects that affect the implementation of smart educationof

\subsection{Discussion}

The order of ranking factors from the most important to the most important or most discussed by the reference is shown in Figure 7.

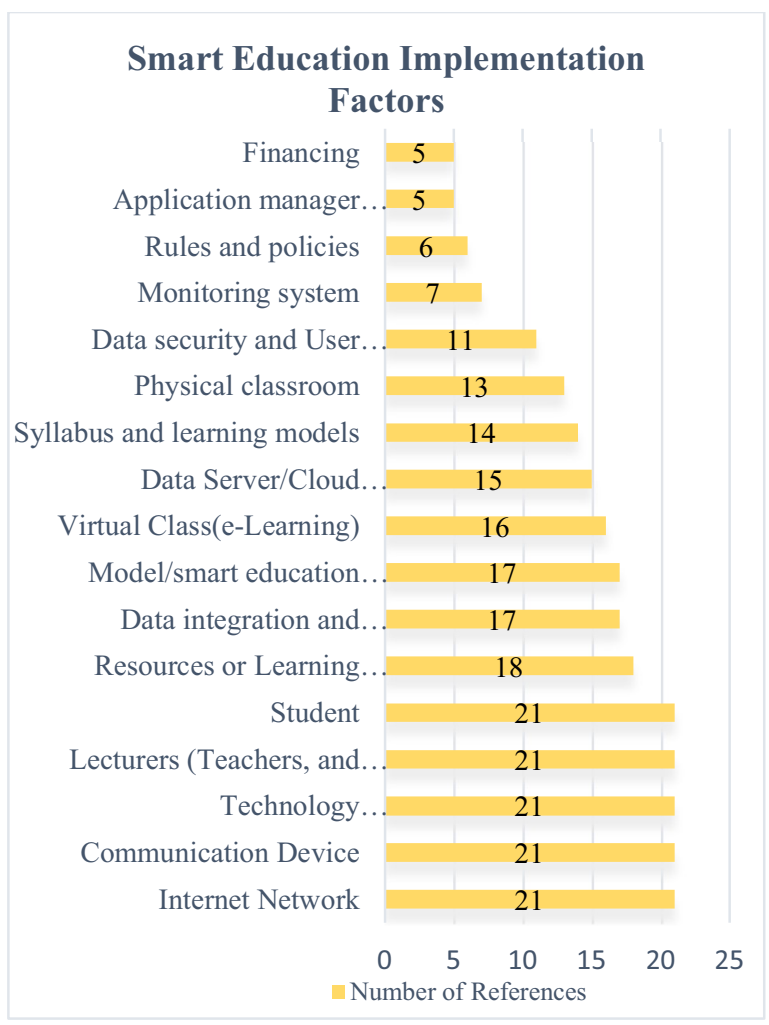

Fig. 7. Ranking factors that influence the implementation of smart education

The following is an explanation of the factors that influence the implementation of the smart education concept.
1. Internet network. It is an infrastructure that must exist in the smart education concept to access data in real time. Internet connection must exist in all areas to be implemented.

2. Communication devices. In the form of tablets, P.C.s, laptops, smartphones, or other devices that can be used to communicate in the learning process.

3. Technological trends. In the form of platforms or applications that have implemented the latest technological innovations, such as teleconference, big data analysis, gamification, artificial intelligence, and others.

4. Teacher. Teachers/lecturers/instructors must be actively involved in the concept of smart education, because they will design the syllabus, deliver materials, and evaluate learning outcomes. Teachers must have innovative ways of utilizing technology.

5. Students. Is a factor that is the main target and determinant of the success of an education system. It should also be noted that family or government support for the facilities needed by students. Not only communication tools, but also time, supervision, and guidance from parents.

6. Resources or learning materials. In the form of learning materials that have been prepared by the teacher. Apart from teachers, students can also access other learning resource materials from the internet to enrich their knowledge.

7. Integration of data and applications. Teachers/students can use the learning platform from various devices such as laptops, smartphones, and tablets to access the same data. Another benefit when a student changes schools, data integration will make it easier for the targeted school to access student data that already exists/filled in from the previous school.

8. Smart education model/framework. The preparation of this framework must consider many factors and be carried out before implementing smart education in a region. In research [12], there are three main elements that must exist in the smart education model, namely smart learning environment, smart pedagogies, and smart learners.

9. Virtual Class. Is a platform used to carry out the learning process, such as through e-learning or teleconference. This virtual class functions as a complement to meetings in real classes, but in certain circumstances, such as during the COVID-19 pandemic, it can be used as a substitute for physical classrooms.

10. Data Server/Cloud Computing. The learning process, especially what is done online, cannot be separated from the need for data storage. Cloud computing technology can increase efficiency and effectiveness in the data storage process, because an organization can hand over all maintenance and security to the provider.

11. Syllabus and learning models are used as a guide for teachers in carrying out learning activities. This strategy should include formal and informal Learning, both in the real world and in the digital world [12]. 
12. Physical classroom/lab. Although almost all learning needs can be accessed online, students still need direct interaction with fellow students or other humans. This classroom is in the form of a learning room with various I.C.T. facilities/media and laboratories used for practicum.

13. Data security and user privacy, can be a major problem if not managed properly. Can be anticipated by using single sign on (SSO) or entrusting system development and data storage to a provider that already has a good security reputation.

14. Monitoring system, is used to monitor the system, evaluate Learning, and anticipate if something unexpected or unexpected happens.

15. Rules and policies. The government's support and role as outlined in the rules or policies will be the initial capital for implementing smart education. Policies must involve all stakeholders involved to accommodate all aspirations and increase the active role of all parties.

16. Application Manager, in the form of an operator or from management in charge of managing systems and applications so that they run according to plan.

17. Financing is an important element in implementation, but in previous studies there were not many references that discussed financing. This element of financing includes not only costs managed by the government related to system development and implementation, but also costs for fulfilling supporting facilities/equipment charged to parents studens.

\section{Conclusion}

Before implementing smart education, the government and all related parties need to pay attention to several things that can later become a determining factor for successful implementation. This research using the Systematic Review method has concluded several things related to these factors. Several factors that need to be considered include aspects of: (i) technology, (ii) data, (iii) human resources, (iv) organization, and (v) cost. These factors can be used as special attention for the government in implementing the smart education concept.

Further research is expected to be able to dig deeper into each of the influencing factors, so as to produce a more detailed picture and the impact of each factor.

Authors say thanks to Dean and Staff of Faculty of Engineering, Universitas Khairun, Ternate, special work by Smart Islands Research Group Laboratory for this pilot Project Research in Northern Maluku.

\section{References}

1. Ireland, S. Ranked: World's Best Countries For Education System, (2020).

2. Toquero, C.M. Challenges and Opportunities for Higher Education amid the COVID-19 Pandemic: The Philippine Context. Pedagog. Res. (2020), 5, em0063, doi:10.29333/pr/7947.

3. Bahasoan, A.N.; Ayuandiani, W.; Mukhram, M.;
... Effectiveness of Online Learning In Pandemic Covid-19. ... J. Sci. ... (2020), 100-106.

4. Setyorini Pandemi Covid-19 Dan Online Learning Apakah Berpengaruh Terhadap Proses Pembelajaran Pada Kurukulum 13? Jiemar (2020), 01, 95-102.

5. (BPS), B.P.S. Statistik Pendidikan Indonesia (2019). 2019, V-195.

6. Arief, A.; Sensuse, D.I. Towards Development of Academic Information System - as-a-Services. (2018), 85-91.

7. Christian, F. Kemana Arah Smart City Setelah Covid-19.

8. Yuliastri, R.; Amani, H. Indicators to Measure a Smart Building: An Indonesian Perspective. Int. J. Comput. Theory Eng. (2017), 9, 406-411, doi:10.7763/ijcte.2017.v9.1176.

9. Harijati, S.; Sadjati, I.M.; Handayani, S.K.; Dkk Optimalisasi Peran Sains \& Teknologi untuk Mewujudkan Smart City; (2017); ISBN 9788578110796.

10. Gaffo, F.; Brigano, G.; Gomede, E.; Barros, R.; Mendes, L. Edukas environment: Towards an integrated dashboard for education management in smart cities. 2017 IEEE SmartWorld Ubiquitous Intell. Comput. Adv. Trust. Comput. Scalable Comput. Commun. Cloud Big Data Comput. Internet People Smart City Innov. SmartWorld/SCALCOM/UIC/ATC/CBDCom/IOP ISCI 2017 - (2018), 1-8, doi:10.1109/UICATC.2017.8397535.

11. Fu'Adi, D.K.; Arief, A.; Sensuse, D.I.; Syahrizal, A. Conceptualizing smart government implementation in smart city context: A systematic review. In Proceedings of the 2020 5th International Conference on Informatics and Computing, I.C.I.C. 2020; (2020).

12. Zhu, Z.-T.; Yu, M.-H.; Riezebos, P. A research framework of smart education. Smart Learn. Environ. (2016), 3, doi:10.1186/s40561-0160026-2.

13. Rawat, A.; Dangwal, K.L. Technologies for Smart Learning. (2017), 7, 11-22, doi:10.5958/22495223.2017.00002.X.

14. Kitchenham, B. Guidelines for performing Systematic Literature Reviews in Software Engineering. IEEE Access (2007), 4.

15. Triandini, E.; Jayanatha, S.; Indrawan, A.; Werla Putra, G.; Iswara, B. Metode Systematic Literature Review untuk Identifikasi Platform dan Metode Pengembangan Sistem Informasi di Indonesia. Indones. J. Inf. Syst. (2019), 1, 63, doi:10.24002/ijis.v1i2.1916.

16. Suwita, J.; Kosala, R.; Ranti, B.; Supangkat, S.H. Factors considered for the success of the Massive Open Online Course in the era of Smart Education: Systematic Literature Review. Proceeding - 2019 Int. Conf. I.C.T. Smart Soc. Innov. Transform. Towar. Smart Reg. ICISS 2019 (2019), 0-4, doi:10.1109/ICISS48059.2019.8969844. 
17. Boell, S.K.; Cecez-Kecmanovic, D. On being "systematic" in literature reviews in I.S. J. Inf. Technol. (2015), 30, 161-173, doi:10.1057/jit.2014.26.

18. Hammad, R.; Ludlow, D. Towards a smart learning environment for smart city governance. Proc. - 9th IEEE/ACM Int. Conf. Util. Cloud Comput. UCC 2016 (2016), 185-190, doi:10.1145/2996890.3007859.

19. Indrawati; Ghassani, U.H.; Amani, H. Measuring smart education readiness index: A bandung perspective. A.C.M. Int. Conf. Proceeding Ser. (2018), 199-203, doi:10.1145/3278252.3278277.

20. Saini, M.K.; Goel, N. How smart are smart classrooms? A review of smart classroom technologies. A.C.M. Comput. Surv. (2019), 52, doi:10.1145/3365757.

21. El Mrabet, H.; Moussa, A.A. Smart school guidance and vocational guidance system through the internet of things. A.C.M. Int. Conf. Proceeding Ser. (2019), Part F1481, doi:10.1145/3320326.3320404.

22. Amasha, M.A.; Areed, M.F.; Alkhalaf, S.; Abougalala, R.A.; Elatawy, S.M.; Khairy, D. The future of using Internet of Things (loTs) and Context-Aware Technology in E-learning. (2020), 114-123, doi:10.1145/3383923.3383970.

23. Ur Rahman, M.; Himanshi; Deep, V.; Rahman, S. I.C.T. and internet of things for creating smart learning environment for students at education institutes in India. Proc. 2016 6th Int. Conf. Cloud Syst. Big Data Eng. Conflu. 2016 (2016), 701-704, doi:10.1109/CONFLUENCE.2016.7508209.

24. Kadar, M. Smart learning environment for the development of Smart City applications. 2016 IEEE 8th Int. Conf. Intell. Syst. I.S. 2016 - Proc. (2016), 59-64, doi:10.1109/IS.2016.7737500.

25. Tian, J.; Zheng, Z. Smart education in Yunnan, China: Present situation and construction measures. 14th Int. Conf. Serv. Syst. Serv. Manag. ICSSSM 2017 - Proc. (2017), doi:10.1109/ICSSSM.2017.7996245.

26. Dneprovskaya, N. V.; Shevtsova, I. V. The Knowledge Management System Development for Smart Education. Proc. 2018 Int. Conf.'"Quality Manag. Transp. Inf. Secur. Inf. Technol. IT QM IS 2018 (2018), 602-606, doi:10.1109/ITMQIS.2018.8525129.

27. Shi, W.; Liu, X.; Gong, X.; Niu, X.; Wang, X.; Jing, S.; Lu, H.; Zhang, N.; Luo, J. Review on Development of Smart Education. Proc. - IEEE Int. Conf. Serv. Oper. Logist. Informatics 2019, SOLI $2019 \quad$ (2019), doi:10.1109/SOLI48380.2019.8955052.

28. Yuliantoputri, A.R.; Muhamad, W.; Suhardi, S. Smart Classroom Services System Design Based on Services Computing System. Proceeding - 2019 Int. Conf. I.C.T. Smart Soc. Innov. Transform. Towar. Smart Reg. ICISS 2019 (2019), doi:10.1109/ICISS48059.2019.8969809.
29. Fetaji, B.; Fetaji, M.; Ebibi, M.; Kera, S. Analyses of Impacting Factors of I.C.T. in Education Management: Case Study. Int. J. Mod. Educ. Comput. Sci. (2018), 10, 26-34, doi:10.5815/ijmecs.2018.02.03.

30. Yasya, W. Rural empowerment through education: Case study of a learning community telecentre in Indonesia. Int. J. Mod. Educ. Comput. Sci. (2020), 12, 12-26, doi:10.5815/ijmecs.2020.04.02.

31. Burbules, N.C.; Fan, G.; Repp, P. Five trends of education and technology in a sustainable future. Geogr. Sustain. (2020), 1, 93-97, doi:10.1016/j.geosus.2020.05.001.

32. Zhuang, R.; Tang, S.; Li, J.; Huang, R. Citizen experiences of smart Learning in China's cities. Smart Learn. Environ. (2017), 4, doi:10.1186/s40561-017-0045-7.

33. Zhuang, R.; Fang, H.; Zhang, Y.; Lu, A.; Huang, R. Smart learning environments for a smart city: from the perspective of lifelong and lifewide Learning. Smart Learn. Environ. (2017), 4, doi:10.1186/s40561-017-0044-8.

34. Dron, J. Smart learning environments, and not so smart learning environments: a systems view. (2018).

35. Ramirez-mendoza, R.P.R.Z.R.A. Smart educational tools and learning management systems: Int. J. Interact. Des. Manuf. (2020), doi:10.1007/s12008-020-00695-4. 